\title{
THE EFFECT OF BOVINE LACTOFERRIN ON THE MICROBIOLOGICAL PROPERTIES OF RAW MILK
}

\begin{abstract}
Ayhan Duran*
Aksaray University, Faculty of Engineering, Department of Food Engineering, Aksaray, Turkey

Received/ Geliş: 23.02.2021; Accepted/ Kabul: 20.04.2021; Published online/ Online bask1: 27.04.2021

Duran, A. (2021). The effect of bovine lactoferrin on the microbiological properties of raw milk. GIDA (2021) 46 (3) 681-691 doi: 10.15237/gida.GD21041

Duran, A. (2021). Sığır laktoferrinin çiğ sütün mikrobiyolojik özelliklerine etkisi. GIDA (2021) 46 (3) 681-691 doi: 10.15237/gida.GD21041

ABSTRACT

Milk is a foodstuff that is very open to contamination depending on the way it is obtained. Also, it is a microbiologically perishable product in terms of the nutritional components it contains. Regarding both regulations and consumer awareness, it cannot be intervened substantially until the process of raw milk in the dairy farms. Therefore, due to the proliferation of Coliforms, especially Psendomonas spp. and lactic acid bacteria, various problems may arise in both product and technology. The present study aimed to investigate the effect of lactoferrin, a natural inhibitor, on the microbiological properties of raw milk kept in the cold chain. As a result of the study, no inhibitory effect of lactoferrin on lactic acid bacteria was observed. However, it showed a significant antibacterial effect by inhibiting the growth of Psendomonas spp. and Coliform $(P<0.05)$. As the lactoferrin concentration increased, the antimicrobial effect increased significantly. This showed that lactoferrin can be used as a natural antimicrobial agent in cold systems of liquid foods.
\end{abstract}

Keywords: Raw milk, lactoferrin, Pseudomonas spp., Coliform, lactic acid bacteria

\section{SIĞIR LAKTOFERRİNİN ÇİĞ SÜTÜN MİKROBİYOLOJİK ÖZELLİKLERİNE ETKISI}

\section{ÖZ}

Sütler elde edilme şekline göre kontaminasyona gayet açı bir gıda maddesidir. Aynı zamanda içerdikleri besin bileşenleri yönünden ise mikrobiyolojik olarak çok hızlı bozulabilen bir üründür. Gerek mevzuatlar yönünden gerekse bilinçli tüketim yönünden çiğ sütlerin işletmelerde işlemeye alınma sürecine kadar çok fazla müdahele edilememektedir. Bu nedenle çiğ sütlerde başta Pseudomonas spp. olmak üzere Koliformlar ve Laktik asit bakterilerin çoğalması nedeniyle gerek üründe gerekse teknolojide çeşitli sıkıntılar ortaya çıkabilmektedir. Çalışmamızda doğal bir inhibitör madde olan laktoferrin ilavesi ile soğuk zincirde tutulan çiğ sütlerin mikrobiyolojik özelliklerine etkisi incelenmiştir. Çalışma neticesinde laktoferrinin laktik asit bakterleri üzerine önemli düzeyde $(p<0.05)$ inhibe edici bir etkisi görülmemiştir. Ancak Pseudomonas spp. ve Koliform bakterilerin çoğalmalarını engelleyerek önemli düzeyde $(\phi<0.05)$ antibakteriyel etki göstermiştir. Laktoferrin konsantrasyonu arttıkça antimikrobiyal etki de önemli düzeyde artmıştır. Bu durum laktoferrinin sıvı gıdaların soğuk sistemlerde doğal bir antimikrobiyal ajan olarak kullanılabileceğini göstermiştir.

Anahtar kelimeler: Çiğ süt, laktoferrin, Pseudomonas spp., koliform, laktik asit bakterisi

${ }^{*}$ Corresponding author/Yazışmalardan sorumlu yazar:

\begin{tabular}{|c|c|c|}
\hline \: aduran@aksaray.edu.tr & (0: (+90) 5428955303 & 冒: (+90) 3822883525 \\
\hline
\end{tabular}




\section{INTRODUCTION}

With the increase in collective life and collective consumption, the necessity of reliable methods for the protection and preservation of food has emerged (Öztürk et al., 2006). The use of artificial or natural antimicrobial agents to prevent or control the growth of pathogenic and deteriorating microorganisms has been an important issue in the food industry in recent years (Payne et al., 1994). In this context, interest in animal and plant-based inhibitors, organic acids, and bacteriocins has increased (Öztürk et al., 2006). It has been known for many years that milk, eggs, some herbs, probiotics, salts, and organic acids are natural antimicrobial agents. However, the structure-function relationship of such bioactive compounds has been put forward scientifically in recent years (Naidu, 2002). In addition to being an important source of milk in human nutrition, it also has a protective effect on infections (Ünal and Akalın, 2008). There are biologically active substances and immune system-supportive compounds in milk that is of importance in the nutrition of newborns and adults. These compounds are bioactive proteins, bioactive lipids, lactoferrin (LF), lactoperoxidase, lysozyme, N-acetyl- $\beta$-D-glucosaminidase (NAGase), and nisin. Lactoperoxidase and lysozyme are the most abundant antimicrobial enzymes in milk, while lactoferrin is the most abundant antimicrobial peptide (Ylmaz and Tosun, 2012). Antimicrobial proteins and peptides are produced by the secretory fluids produced by many organisms as a primary defense mechanism (Matijašic et al., 2020).

Lactoferrin is a member of the transferrin protein family and is an iron-binding glycoprotein. Lactoferrin is assumed to be the strongest antimicrobial agent in milk. Lactoferrin is produced in the mucosal epithelial cells of humans, cows, horses, dogs, and some rodents (Sebastián-Nicolás et al., 2020). Recent studies have shown that lactoferrin is also produced from trout eggs in fish using molecular biology techniques. This glycoprotein is abundantly found in colostrum and is the most abundant protein in milk after the casein. It is also found in body fluids such as blood plasma and amniotic fluids in addition to mucosal secretions such as tears, saliva, vaginal fluid, and urine. Lactoferrin is found at $1.5-5.0 \mathrm{mg} / 1$ in cow colostrum and approximately $100 \mu \mathrm{g} / \mathrm{ml}$ in milk. It is found at the level of $6-8 \mathrm{mg} / \mathrm{ml}$ in human colostrum and $20-200 \mu \mathrm{g} / \mathrm{ml}$ in milk (Steijns and vanHooijdonk, 2000). This shows the importance of lactoferrin for humans, especially infants (Gür et al., 2010). Bovine lactoferrin consists of 689 amino acids and human lactoferrin consists of 691 amino acids, and their sequence similarity rate is $69 \%$. The three-dimensional structure of bovine and human lactoferrin is very similar but not identical (Steijns and van-Hooijdonk, 2000). Lactoferrin is a glycosylated protein with a molecular weight of $80 \mathrm{kDa}$ and approximately 700 amino acids. It is a simple polypeptide-chain coiled into two symmetrical lobes ( $\mathrm{N}$ and $\mathrm{C}$ lobes) very similar to each other. The 1-332 amino acids of this polypeptide chain form the parts of the $\mathrm{N}$ lobe while the 334-703 amino acids form the $\mathrm{C}$ lobe. Both lobes have the ability to bind iron ions in the form of both $\mathrm{Fe}^{+2}$ and $\mathrm{Fe}^{+3}$. Lactoferrin is a positively charged protein with an isoelectric point of 8.0-8.5 (Gonzalez-Chavez et al., 2009). Approximately $5-30 \%$ of a saturated lactoferrin molecule consists of iron ions. Lactoferrin containing $5 \%$ iron is called apolactoferrin, and lactoferrin saturated with iron is called hololactoferrin. Lactoferrin in human milk is found in the form of apolactoferrin (Alkın, 2008).

The antimicrobial activity of lactoferrin is mostly explained by two mechanisms. The first known antimicrobial property of lactoferrin is to prevent microbial growth by binding iron ion, which is the food source of the microorganism. For a long time, this was believed to be the only antimicrobial activity of lactoferrin (Branen and Davidson, 2000), and this antimicrobial activity was explained by the strong iron-binding capacity of apolactoferrin (Papademas et al., 2021). It has been reported iron deprivation leads to inhibition of cellular proliferation (Naidu, 2002). Normally, lactoferrin saturated with 6-8\% iron in biological fluids, competes with siderophores to bind free iron, negatively affecting the growth of the bacteria. These effects are bacteriostatic on yeasts, Gram (+), and Gram (-) bacteria (Avc1, 
2007). While these effects are strong for bacteria with high iron needs, these effects may decrease for bacteria with low iron needs (Temiz et al., 2008). The second mechanism is the direct interaction of the infectious agent and lactoferrin. The positive amino acids in lactoferrin interact with Gram (+) and Gram (-) and anionic molecules on the surface of acid and alcoholresistant bacteria, leading to the destruction of the cells (Gonzalez-Chavez et al., 2009). The interaction of lactoferrin with the cell surface of Gram (-) bacteria is of importance. Lactoferrin potentially targets porins that allow molecules to pass through the membrane to bind (Alkın, 2008). The $\mathrm{N}$ lobe of lactoferrin with a strong cationic structure interacts with the anionic structure of Lipopolysaccharide (LPS) in the bacterial membrane, increasing the instability of the membrane and causing the LPS to separate from the membrane. As a result, membrane permeability increases, and bacteria are damaged (Steijns and van-Hooijdonk, 2000). The action mechanism of lactoferrin against Gram (+) bacteria is that the strongly positively charged part binds to anionic molecules on the bacterial surface and generally chooses lipoteichoic acid as the target. As a result of binding, the anionic structure of the cell is reduced and the interaction between the peptidoglycan layer in the bacterial cell wall and the lysozyme enzyme secreted from the mucosa is facilitated (Gonzalez-Chavez et al., 2009). As a result of this interaction between lactoferrin and lipopolysaccharide, the outer membrane is damaged with the effect of the antibacterial lysozyme enzyme (Yilmaz and Tosun, 2012). These reactions indicate that lactoferrin has also bactericidal properties against Gram (+) and Gram (-) bacteria (GonzalezChavez et al., 2009). Lactoferrin's iron-binding stability has a wide $\mathrm{pH}$ limit and can form iron chelates even in very acidic environments such as $\mathrm{pH}$ 3. Although lactoferrin is highly resistant to proteolytic and oxidative degradation (Erga et al., 2000), it is sensitive to high temperatures (Wakabayashi et al., 2006). Also, lactoferricin, formed as a result of the degradation of lactoferrin by the enzyme pepsin, is thought to be responsible for the antimicrobial activity of lactoferrin and it has been reported that its bactericidal effect is 100 -fold higher than that of lactoferrin (Duran and Kahve, 2017). Some researchers have investigated the antimicrobial effects of lactoferrin on various foodstuffs. Taylor et al. (2004) carried out researches and reported the antimicrobial effects of lactoferrin on the beef carcass, Al-Nabulsi et al. (2007) on dry sausages, Colak et al. (2008) on meatballs, Enrique et al. (2008) on wine, Del Olmo et al. (2012) on the chicken fillet, Quintieri et al. (2012) on Mozarella cheese, Bravo et al. (2014) on red meat, Montiel et al. (2016) on ham, and Padrão et al. (2016) on the fresh sausage. However, the studies on milk are very limited.

The most important disadvantage is that the milk spoils in a short time as well as the production difficulty. Microbiological deterioration is the biggest factor in milk spoilage. Milk constitutes a good growth environment for microorganisms due to its rich composition. Microorganisms contaminate milk from various sources (dust, air, soil, human, the animal itself, tools, and equipment), especially milking conditions (Claeys et al., 2013). The main carbohydrate of milk is lactose. A limited number of microorganisms have the ability to obtain energy from lactose. Therefore, microorganisms with enzymes that hydrolyze lactose (lactic acid bacteria, Coliform group bacteria, and some of the Gram-negative bacteria) are more advantageous than other microorganisms. These microorganisms cause various deteriorations in milk such as rancidity and coagulation as a result of lactic acid production (Quigley et al., 2013). Milk factories obtain the raw materials they need from milk production units. Although small farms have the opportunity to supply milk as much as their daily needs from the immediate environment, large enterprises have to obtain milk from more distant centers and especially from large capacity production units, since their needs are high. In this case, it is not possible for the milk to reach the enterprise on the same day, and various quality problems occur (O'Connell et al., 2016). Raw milk is cold stored in farms or milk collection centers and then delivered to factories by refrigerated tankers (Walstra et al., 2006). However, albeit slowly, bacteria normally present in milk during 
cold storage continue to develop, (Capodifoglio et al., 2016). The process that raw milk goes through from the producer to the factory is the basis of milk quality problems (Melda, 2019) and the source of milk spoilage (Walstra et al., 2006). The most effective bacteria groups in this process are lactic acid bacteria, Coliform bacteria, and psychrotroph bacteria, respectively. More than $50 \%$ of psychrotroph bacteria are Pseudomonas spp. (Walstra et al., 2006). The main way of avoiding the spoilage process of raw milk and maintaining the natural quality of the milk is to halt its bacterial activity (Ruusunen et al., 2013). The present study aimed to investigate the effect of different bovine lactoferrin (bLF) concentrations on the microbiological quality of raw milk that must be kept cold for a long time.

\section{MATERIALS AND METHODS}

\section{Preparation of milk and lactoferrin solution}

The raw milk used in the present study was cow's milk due to its commercial value and was provided by Aksaray Cattle Breeders Association. After milking, the raw milk was brought to the laboratory via directly-cooled vehicles and cooled. The temperature and duration of the cold environment, the time-temperatures of the raw milk commercially in storage tanks and milk tankers were taken as reference. Accordingly, the temperature was $10 \pm 2{ }^{\circ} \mathrm{C}$ and the time was 36 hours. Chemical analyzes of raw milk were performed in Aksaray TBMYO Private Food Control Laboratory and the results are shown in Table 1.

Table 1. Chemical analysis results of raw milk

\begin{tabular}{lc}
\hline Humidity $\%$ & $87.70 \pm 0.04$ \\
Fat $(\%)$ & $3.58 \pm 0.02$ \\
Protein $(\%)$ & $3.30 \pm 0.02$ \\
Lactose $(\%)$ & $4.75 \pm 0.03$ \\
$\mathrm{pH}$ & $6.68 \pm 0.01$ \\
Lactic acid $(\%)$ & $0.135 \pm 0.001$ \\
\hline
\end{tabular}

The lactoferrin used in the study was used as pure $(85 \%)$ lactoferrin (Sigma, L9507) obtained from cow's milk. Lactoferrin was dissolved in steriledeionized water and a $20 \mathrm{mg} / \mathrm{mL}$ stock solution was prepared first. Three different concentrations, $0 \mathrm{mg} / \mathrm{mL}, 2.5 \mathrm{mg} / \mathrm{mL}$ and 5.0 $\mathrm{mg} / \mathrm{mL}$ (Payne et al., 1994; Murdock and Matthews, 2002; Quintieri et al., 2019) were used in the study. The lactoferrin solutions prepared were added to the raw milk stored in three different containers. Microbiological analyzes were carried out by taking samples from coldstored milk at $0,12,24$, and 36 hours according to the ISO/FDIS 8086 (2004) method.

\section{Microbiological analyses}

Colony counts were performed for lactic acid bacteria using Man Rogosa Sharpe Agar (Oxoid, CM1153) (ISO 15214: 1998). Incubation for lactic acid bacteria count was performed at $30 \pm 2{ }^{\circ} \mathrm{C}$ for 72 hours under anaerobic conditions. After incubation, white and opaque colonies were enumerated. For the confirmation test, samples were taken from the colonies, and Gram-staining, cellular shape under a microscope, and catalase tests with hydrogen peroxide were performed. Colony enumerations were performed for total Coliform bacteria using the Violet Red Bile Agar (Oxoid, CM0978) medium (APHA, 1992). Incubation for Coliform bacteria count was performed at $32 \pm 2{ }^{\circ} \mathrm{C}$ for 24 hours. Following the incubation, the number of ringed purple-red appearing colonies was determined. Samples were taken from the colonies for validation testing and inoculated into Brilliant Green Lactose Broth (Merck, 16025) tubes. The samples were checked for gas production after 48 hours at $35 \pm 2{ }^{\circ} \mathrm{C}$. Pseudomonas spp. enumerations were performed using Pseudomonas Agar (Bioneks BM15608) medium supplemented with Penicillin and Pimarisin. Pseudomonas spp. colonies were counted after $25^{\circ} \mathrm{C} \pm 2{ }^{\circ} \mathrm{C}$ incubation for 48 hours. Samples taken randomly from Petri dishes with a colony number of less than 150 were proliferated on Nutrient Agar (Merck, 105450). Oxidase and glucose fermentation (TGE Agar, Oxoid CM0127) validation tests were applied to these samples. Pseudomonas spp. were characterized by a positive reaction to the oxidase test and a negative response to glucose fermentation (ISO/TS 11059:2009). Bacterial count results in the study are given as $\log \mathrm{CFU}$ (colony forming units) $/ \mathrm{mL}$. 


\section{Statistical analyses}

All the analyses were carried out in four replicates and the data obtained as a result of the analyses were subjected to analysis of variance (ANOVA) using the SPSS 22.0.0 package software (SPSS Inc., Chicago, USA). The Duncan analysis was adopted to compare the effects of statistically different concentrations $(0,0.25,0.50 \mathrm{mg} / \mathrm{mL}$ LF), while the General Linear Model Repeated Measures analysis was used to compare the effects of retention times $(0,12,24,36$ hours). The differences between the mean values were considered significant at $p<0.05$.

\section{RESULTS AND DISCUSSIONS}

The data obtained as a result of the study are given in Table 2. The samples were divided into three groups as LF-free milk, $2.5 \mathrm{mg} / \mathrm{mL}$ - and 5.0 $\mathrm{mg} / \mathrm{mL}-\mathrm{LF}$ milk according to the method of administration, and changes both within groups and according to time were investigated. Comparing the growth rate in LF-free milk, from Table 2. high to low, it was sorted as Pseudomonas spp., Coliforms, and lactic acid bacteria, respectively. The highest growth rate was $5.07 \pm 0.07 \mathrm{log}$ $\mathrm{CFU} / \mathrm{mL}$ in Pseudomonas spp. While mesophilic bacteria are kept to a minimum during cold storage and transportation, psychrotrophic bacteria, especially Pseudomonas species, dominate the microbiota of raw milk (Tanaka et al., 2018). Although the optimum temperatures of Lactic acid bacteria and Coliforms in raw milk are above $20{ }^{\circ} \mathrm{C}$ (Walstra et al., 2006), there are some species of the Coliform bacteria group that can grow rapidly even at 5-7 ${ }^{\circ} \mathrm{C}$ (Robinson, 2005). The number of Coliform bacteria increased at a higher rate $(3.62 \pm 0.08 \log \mathrm{CFU} / \mathrm{mL})$ during the maintenance period compared to Lactic acid bacteria $(2.99 \pm 0.10 \log \mathrm{CFU} / \mathrm{mL})$. Lactic acid bacteria are common in milk and dairy products, Gram-positive, thermophilic-mesophyllic, and generally potentially probiotic (Giraffa, 2012).

Table 2 . The microbial changes in the raw milk during storage $\left(10 \pm 2{ }^{\circ} \mathrm{C}\right)$.

\begin{tabular}{|c|c|c|c|c|}
\hline & Hour 0 & Hour 12 & Hour 24 & Hour 36 \\
\hline \multicolumn{5}{|c|}{ Lactic acid bacteria (log CFU/mL) } \\
\hline Milk & $1.96 \pm 0.05^{\mathrm{d}}$ & $2.25 \pm 0.05^{\mathrm{c} 1}$ & $2.86 \pm 0.06^{\mathrm{b} 1}$ & $2.99 \pm 0.10^{\mathrm{a} 1}$ \\
\hline Milk + LF (2.5 mg/mL) & $1.96 \pm 0.05^{\mathrm{d}}$ & $2.25 \pm 0.05^{\mathrm{c} 1}$ & $2.63 \pm 0.06^{\mathrm{b} 2}$ & $2.84 \pm 0.06^{\mathrm{a} 1}$ \\
\hline Milk + LF (5.0 mg/mL) & $1.96 \pm 0.05^{\mathrm{d}}$ & $2.24 \pm 0.06^{\mathrm{c} 1}$ & $2.44 \pm 0.05^{\mathrm{b} 3}$ & $2.56 \pm 0.06^{a 2}$ \\
\hline \multicolumn{5}{|c|}{ Coliforms $(\log \mathrm{CFU} / \mathrm{mL})$} \\
\hline Milk & $2.06 \pm 0.06^{\mathrm{d}}$ & $2.87 \pm 0.05^{\mathrm{c} 1}$ & $3.41 \pm 0.09 \mathrm{~b} 1$ & $3.62 \pm 0.08^{a 1}$ \\
\hline Milk + LF (2.5 mg/mL) & $2.06 \pm 0.06^{\mathrm{d}}$ & $2.86 \pm 0.06^{\mathrm{c} 1}$ & $3.19 \pm 0.09 \mathrm{~b} 2$ & $3.25 \pm 0.06^{\mathrm{a} 2}$ \\
\hline Milk + LF (5. mg/mL) & $2.06 \pm 0.06^{c}$ & $2.52 \pm 0.04 \mathrm{~b} 2$ & $3.08 \pm 0.07 \mathrm{a} 2$ & $3.19 \pm 0.08^{\mathrm{a} 2}$ \\
\hline \multicolumn{5}{|c|}{ Pseudomonas spp. $(\log \mathrm{CFU} / \mathrm{mL})$} \\
\hline Milk & $1.56 \pm 0.06^{\mathrm{d}}$ & $2.42 \pm 0.08^{\mathrm{c} 1}$ & $4.28 \pm 0.63 \mathrm{~b} 1$ & $5.07 \pm 0.07 \mathrm{a}_{1}$ \\
\hline Milk + LF $(2.5 \mathrm{mg} / \mathrm{mL})$ & $1.56 \pm 0.06^{\mathrm{d}}$ & $2.26 \pm 0.22^{\mathrm{c} 12}$ & $2.97 \pm 0.07 \mathrm{~b} 2$ & $3.23 \pm 0.08^{\mathrm{a} 2}$ \\
\hline Milk + LF (5.0 mg/mL) & $1.56 \pm 0.06^{c}$ & $1.98 \pm 0.07 \mathrm{~b} 2$ & $2.83 \pm 0.06^{\mathrm{a} 2}$ & $2.87 \pm 0.06^{\mathrm{a} 3}$ \\
\hline
\end{tabular}

Bearing different superscripts row-wise (alphabet) and column wise (numeric) differ significantly $(p<0.05)$.

In the present study, lactic acid bacteria counts increased in all three groups (LF-free, treated with $2.5 \mathrm{mg} / \mathrm{mL}$ and $5.0 \mathrm{mg} / \mathrm{mL} \mathrm{LF}$ ) during the storage period, albeit slightly. As seen in Table 2, there was no significant effect of lactoferrin on the growth rate of lactic acid bacteria. Evaluating the storage periods separately, Lactic acid bacteria counts were found to be lower $(2.56 \pm 0.06 \mathrm{log}$ $\mathrm{CFU} / \mathrm{mL}$ ) compared to the other two groups at the end of 36 hours of storage and in the milk with $5.0 \mathrm{mg} / \mathrm{mL} \mathrm{LF}$. These results showed us that although lactoferrin does not have a stopping effect on Lactic acid bacteria in milk, it can only be effective at $5.0 \mathrm{mg} / \mathrm{mL} \mathrm{LF}$ after 36 hours of storage. Kim et al. (2016), similar to our study, studied the antibacterial effect of bovine lactoferrin on some Lactic acid bacteria species, Coliform and Pseudomonas bacteria. The 
researchers used synthetic peptides containing the C-lobe sequence of lactoferrin instead of bovine lactoferrin. They performed trials on Escherichia coli in the Coliform group, Pseudomonas fluorescens and Pseudomonas syringae in the Pseudomonas group, and Lactobacillus acidophilus in the lactic acid group. Accordingly, it was measured every 6 hours and left to incubation for 24 hours and antimicrobial effects at different doses $(0.75,1.5,3.0 \mathrm{mg} / \mathrm{mL})$ were examined. As a result of the measurements, the proliferation of Pseudomonas fluorescens, Pseudomonas syringae, and Escherichia coli were prevented. Also, as the dose increased, the antimicrobial effect increased. However, no bacteriostatic effect was observed on Lactobacillus acidophilus. Matijašic et al., (2020) examined the antimicrobial effects of seven different lactoferrins isolated from whey and produced in the pilot plant by the disk diffusion method. Escherichia coli, Staphylococcus aureus, Listeria monocytogenes, Salmonella enterica, Clostridium difficile, Klebsiella oxytoca, and Clostridium perfringens were selected as potentially pathogenic indicator bacteria. Lactobacillus acidophilus, Lactobacillus renteri, Lactobacillus gasseri, Lactobacillus delbrueckii, Streptococcus thermophilus, Lactobacillus plantarum, Lactobacillus paracasei, and Lactobacillus casei were selected as lactic acid bacteria. As a result of the study, partial or complete inhibitory properties were observed on all bacteria except for lactic acid bacteria and Clostridium bacteria. The resistance of lactic acid bacteria to lactoferrin inhibition has been associated with their probiotic properties (Chen et al., 2013).

The Coliform counts in LF-free milk and milk supplemented with $2.5 \mathrm{mg} / \mathrm{mL}$ LF continued to increase during the storage period. On the other hand, the Coliform count was $3.08 \pm 0.07 \mathrm{log}$ $\mathrm{CFU} / \mathrm{mL}$ at the end of 24 hours of storage in the $5.0 \mathrm{mg} / \mathrm{mL} \mathrm{LF}$ group, while it was counted as $3.19 \pm 0.08 \log \mathrm{CFU} / \mathrm{mL}$ at the end of 36 hours. The Coliform bacteria count remained virtually constant. It was shown that a high rate of LF solution $(5.0 \mathrm{mg} / \mathrm{mL})$ almost stopped the growth rate of Coliforms at the end of a 24-hour-storage. As seen in Table 2, $5.0 \mathrm{mg} / \mathrm{mL}$ LF started to have a significant effect on Coliforms from the 12th hour. The effect of $2.5 \mathrm{mg} / \mathrm{mL}$ LF level on
Coliform bacteria was found to be significant after 24 hours of storage. Examining the bacterial counts Colifroms during storage, it was reported that this effect was not in a growth-inhibiting way, but in a growth-slowing way. After 36 hours of storage, Coliform counts in milk with $2.5 \mathrm{mg} / \mathrm{mL}$ $\mathrm{LF}$ was measured to be $3.25 \pm 0.06 \log \mathrm{CFU} / \mathrm{mL}$, and $3.62 \pm 0.08 \log \mathrm{CFU} / \mathrm{mL}$ in LF-free milk. In the present study, the result related to the inhibitory effect of bLF on Coliform bacteria was consistent with the results previously reported by some researchers. Naidu et al., (1993) investigated the antimicrobial relationship between bovine lactoferrin (bLF) and Coliforms such as Escherichia coli and Salmonella typhimurium. The researchers have stated that lactoferrin had a bacteriostatic effect on these Coliform bacteria and this effect was explained by a third theory of action mechanism. Accordingly, the mechanism is that Lactoferrin binds to these structures with some ligands instead of directly binding to Lipopolysaccharides or Porins. As a result, the researchers have reported that bLf would damage the outer membrane of Coliform bacteria and cause bacteriosis with changes in permeability. Kutila et al. (2003) investigated the antibacterial effect of bovine lactoferrin on Gram-negative and Gram-positive pathogens. The researchers studied Escherichia coli and Pseudomonas aeruginosa as Gram-negative bacteria, Staphylococcus aureus, and coagulase-negative staphylococci (CNS) as Grampositive bacteria. The incubation period in the study was 20 hours, and the LF concentrations used were $0.67 \mathrm{mg} / \mathrm{ml}, 1.67 \mathrm{mg} / \mathrm{ml}$, and 2.67 $\mathrm{mg} / \mathrm{ml}$. Accordingly, the inhibition effect increased with increasing concentration of lactoferrin. The most effective inhibitory activity of LF was seen against Gram-negative E. coli and $P$. aeruginosa. The effect of lactoferrin on the release of LPS to Gram-negative bacteria and damage to the outer membrane of the bacteria (Appelmelk et al., 1994) has revealed the view that Gram-positives is more than damaging through basic nutritional deficiency by disconnecting Fe uptake. This result can be considered as another reason for the weak inhibitory effect of lactoferrin on lactic acid bacteria in the present study. Also, Komine et al. (2005) examined the antimicrobial effect of bovine lactoferrin (bLF) on E. coli in milk 
with mastitis. The researchers have reported that the addition of $0.5 \mathrm{mg} / \mathrm{mL}$ and $1.0 \mathrm{mg} / \mathrm{mL}$ bovine lactoferrin (bLF) in milk stored for 24 hours inhibited the growth of this bacteria. Padrão et al., (2016) applied edible film coatings to give antimicrobial properties to the casings of fresh sausages. The researchers revealed that the casings supplemented with bovine lactoferrin (bLF) showed a bactericidal effect on E. coli in the Coliform group. Komine et al., (2005) and Padrão et al., (2016) associated the inhibition effect of bLF on these bacteria with the ability of bLF to chelate iron ions.

As seen in Table 2, the Pseudomonas spp. counts in LF-free milk and $2.5 \mathrm{mg} / \mathrm{mL} \mathrm{LF}$ continued to increase during the storage period. On the other hand, at the end of 24-hour storage, the Pseudomonas counts in the $5.0 \mathrm{mg} / \mathrm{mL}$ LF group were significantly lower. While this number was $2.83 \pm 0.06 \log \mathrm{CFU} / \mathrm{mL}$ during 24 hours of storage, it was measured as $2.87 \pm 0.06 \log$ $\mathrm{CFU} / \mathrm{mL}$ at the end of 36 hours. This shows the bacteriostatic effect of LF $(5.0 \mathrm{mg} / \mathrm{mL})$ on Pseudomonas spp. Also, both $2.5 \mathrm{mg} / \mathrm{mL}$ and 5.0 $\mathrm{mg} / \mathrm{mL}$ bLF were showed a significant slowing effect on Pseudomonas from the 12th hour of storage. At the end of storage, the effect of 5.0 $\mathrm{mg} / \mathrm{mL}$ LF on Pseudomonas was much higher than the solution at $2.5 \mathrm{mg} / \mathrm{mL} \mathrm{LF}$. At the end of storage, Pseudomonas spp. counts in LF-free milk were found to be as $5.07 \pm 0.07 \log \mathrm{CFU} / \mathrm{mL}$, while it was determined to be $3.23 \pm 0.08$ and 2.87 $\pm 0.06 \log \mathrm{CFU} / \mathrm{mL}$ in the groups treated with 2.5 and $5.0 \mathrm{mg} / \mathrm{mL} \mathrm{LF}$, respectively. The dominant microorganisms that limit the shelf life of chilled raw milk (tank milk) are Pseudomonas spp. (Ternström et al., 1993). Kim et al. (2008) studied the antimicrobial effect of bovine lactoferrin on Pseudomonas spp. The activity of lactoferrin added to liquid media activity at different concentrations $(15,7.5,3.8,1.9,0.9$, and $0.45 \mathrm{mg} / \mathrm{mL}$ ) against Pseudomonas spp. was investigated. The researchers found that lactoferrin inhibited the growth of the tested Pseudomonas strains. The higher the lactoferrin concentration, the higher the antibacterial effect proportionately. The researchers also found bovine lactoferrin ligands with a different molecular mass in all strains. Based on these results, it was concluded that the interaction mechanism between the lactoferrin molecule and Psendomonas spp. was related to the ligands found in bacterial cells. At the end of the study, it has been reported that bovine lactoferrin can be used in dairy products, raw milk, and fruit products for protection from pathogenic bacteria. Among Pseudomonas spp., some species cause important respiratory disorders such as cystic fibrosis and are highly resistant to antibiotics (Hector et al., 2014). The most important of these is Pseudomonas aeruginosa, which is a clinical pathogen and forms a resistant biofilm. Kamiya et al. (2012) investigated the effect of lactoferrin at different concentrations $(0.5,2.0,10 \mathrm{mg} / \mathrm{mL})$ during seven days of incubation in preventing biofilm development of clinical isolates of Pseudomonas aeruginosa. Lactoferrin had an inhibitory effect on biofilm formation in eight of the nine clinical isolates after one-day-incubation. This effect is explained by lactoferrin's iron-chelating properties.

\section{CONCLUSION}

There are great risks in raw products that are liquid like milk and are transported and stored in metal tanks along the cold chain (Brooks and Flint, 2008). It is important that some species of Coliforms and Pseudomonas (some strains of $P$. fluorescens and P. aeruginosa) are pathogenic (Meier et al., 2018). In the present study, it was investigated whether the natural inhibitory substance lactoferrin can be used in combination with the cold chain in the process from the moment the raw milk obtained from the animal to the process in the farm, and how it will cause a change in the microbiological quality of the milk. As a result of the study, lactoferrin did not significantly inhibit the growth of lactic acid bacteria. On the other hand, showed antibacterial effects on Pseudomonas spp. and Coliforms. As the lactoferrin concentration increased, the antibacterial effect increased. This study showed that bovine lactoferrin can be used in products that will not undergo heat treatment for a certain period or avoid the pathogenic properties of bacteria. 


\section{CONFLICT OF INTEREST}

The author declares no conflict of interest.

\section{ACKNOWLEDGEMENTS}

The author would like to thank Aksaray University Scientific Research Projects (Project No: 2015-016) for their support of a large part of this work.

\section{REFERENCES}

Al-Nabulsi, A.A., Holley, R.A. (2007). Effects of Escherichia coli $\mathrm{O} 157: \mathrm{H} 7$ and meat starter cultures of bovine lactoferrin in broth and microencapsulated lactoferrin in dry sausage batters. Int Food Microbiol, 113: 84-91, https://doi.org/10.1016/j.ijfoodmicro.2006.07.0 19.

Alkın, E. (2008). Laktoferrin ve gidalarda kullanımı. Gida ve Yem Bilimi Teknolojisi, 10: 31-38.

APHA (1992). In: Standard Methods for the Examination of Dairy Products, Marshall, R.T. (Ed)., 16th ed., American Public Health Association. Washington, DC., p.546.

Appelmelk, BJ., Yun-qing, A., Geerts, M., Thijs, BG., Boer, HA., Maclaren, DM., Graaff, J., Nuijens, JH. (1994) Lactoferrin is a lipid Abinding protein. Infect. Immun., 62: 2628-2632.

Avc1, G. (2007). Laktoferrinin Biyolojik Özellikleri ve Hastalıklarla İlişkisi. Afyon Kocatepe Üniv. Fen ve Mühend Bilimleri Derg, 7 (1): 23-34.

Barbiroli, A., Bonomi, F., Capretti., Iematti, S., Manzoni, M., Piergiovanni L., Rollini, M. (2012). Antimicrobial activity of lysozyme and lactoferrin incorporated in cellulose-based food packaging. Food Control, 26: 387-392, https://doi.org/ 10.1016/j.foodcont.2012.01.046.

Branen, J. and Davidson, P.M. (2000) Activity of hydrolysed lactoferrin against foodborne pathogenic bacteria in growth media: the effect of EDTA. Lett of Appl Microbiol, 30: 233-237, https://doi.org/10.1046/j.1472-

765x.2000.00711.x.

Bravo, D., de Alba, M., Medina, M. (2014). Combined treatments of high-pressure with the lactoperoxidase system or lactoferrin on the inactivation of Listeria monocytogenes, Salmonella enteritidis and Escherichia coli O157:H7 in beef carpaccio. Food Microbiol, 41: 27-32, https://doi.org/10.1016/j.fm.2014.01.010.

Brooks, J.D., Flint, S.H. (2008). Biofilms in the food industry: problems and potential solutions. Int Food Sci and Technol, 43: 2163-2176, https://doi.org/10.1111/j.1365-

2621.2008.01839.x.

Capodifoglio, E., Vidal, A.M.C., Lima, J.A.S., Bortoletto, F., D'Abreu, L.F., Gonçalves, A.C.S., Vaz, A.C.N. (2016). Lipolytic and proteolitic activity of Pseudomonas spp. isolated during milking and storage of refrigated raw milk, J. Dairy Sci., 99: 5214-5223, http://dx.doi.org/10.3168/jds.201510453.

Chen, P.W.; Jheng, T.T.; Shyu, C.L.; Mao, F.C. (2013). Antimicrobial potential for the combination of bovine lactoferrin or its hydrolysate with lactoferrin-resistant probiotics against foodborne pathogens. J Dairy Sci., 96: 1438-1446. https://doi.org/10.3168/jds.20126112.

Claeys, W.L., Cardoen, S., Daube, G., Block, JD., Dewettinck, K., Dierick, K., Zutter, LD., Huyghebaert, A., Imberechts, H., Thiange, P., Vandenplas, Y., Herman, L. (2013). Raw or heated cow milk consumption: review of risks and benefits. Food Control, 31: 251-262, http://dx.doi.org/10.1016/j.foodcont.2012.09.0 35.

Colak, H., Hampikyan, H., Bingol, E.B., Aksu, H. (2008). The effect of nisin and bovine lactoferrin on the microbiological quality of turkish-style meatball (tekirdağ köfte). J Food Safety, 28: 355375, https://doi.org/10.1111/j.17454565.2008.00105.x.

Del Olmo, A., Calzada, Nunez, M. (2012). Effect of lactoferrin and its derivatives, high hydrostatic pressure, and their combinations, on Escherichia coli O157:H7 and Pseudomonas fluorescens in chicken filets. Innovative Food Sci \& Emerg Technol, 13: 5156, https://doi.org/10.1016/j.ifset.2011.07.016.

Duran, A., Kahve, H.I. (2017). The use of lactoferrin in food industry, Academic J Sci, 07(02): 89-94. 
EFSA (2012). Scientific opinion on bovine lactoferrin, Eur Food Saf Authority J, Vol. 10, Iss. 5, https://doi.org/10.2903/j.efsa.2012.2701.

Enrique, M., Marcos, J.F., Yuste, M., Martínez, M., Vallés, S., Manzanares, P. (2008). Inhibition of the wine spoilage yeast Dekkera bruxellensis by bovine lactoferrin-derived peptides. Int J Food Microbiol, 127: 229-234, https://doi.org/ 10.1016/j.ijfoodmicro.2008.07.011.

Erga, K.S., Peen, E., Tenstad, O., Reed, R.K. (2000). Lactoferrin and anti-lactoferrin antibodies: Effects of ironloading of lactoferrin on albumin extravasation in different tissues in rats. Acta Physiologica Scandinavica, 170(1): 11-19, https://doi.org/10.1046/j.1365-

201x.2000.00754.x.

Giraffa, G. (2012). Selection and design of lactic acid bacteria probiotic cultures. Eng. Life Sci., 12(4): 391-398. https://doi.org/10.1002/ elsc.201100118.

Gonzalez-Chavez, S.A., Arevalo Gallegos, S., Roscon Cruz, Q. (2009). Lactoferrin: structure, function and applications. Int $J$ Antimicrobial Agents, 33(4): 301.e1-301.e8, https://doi.org/ 10.1016/j.ijantimicag.2008.07.020.

Gür, F., Güzel, M., Öncül, N., Yıldırım, Z., Yıldırım M. (2010). Süt serum proteinleri ve türevlerinin biyolojik ve fizyolojik aktiviteleri. Akademik Gida, 8(1): 23-31.

Hector, A., Kröner, C., Carevic, M., Bakele, M., Rieber, N., Riethmüller, J., Griese, M., Zissel, G., Hartl, D. (2014). The chemokine CCL18 characterises Pseudomonas infections in cystic fibrosis lung disease. Eur Respir J., 44: 1608-1615, https://doi.org/10.1183/09031936.00070014.

ISO 15214 (1998). Microbiology of food and animal feeding stuffs. Horizontal method for the enumeration of mesophilic lactic acid bacteria. Colony-count technique at $30{ }^{\circ} \mathrm{C}$. International Organization for Standardization, Geneve, Switzerland.

ISO/FDIS 8086 (2004). Dairy plant - hygiene conditions - General guidance on inspection and sampling procedures. Final Draft international standard. Geneva, $\mathrm{CH}$ : International
Organization for Standardization. Geneva, Switzerland.

ISO/TS 11059 (2009). Milk and milk products. Method for the enumeration of Pseudomonas spp., International Standardization Organization ed., Geneva, Switzerland.

Kamiya, H., Ehara, T. ve Matsumoto T. (2012). Inhibitory effects of lactoferrin on biofilm formation in clinical isolates of Pseudomonas aeruginosa. J Infect Chemother, 18: 47-52, https://doi.org/10.1007/s10156-011-0287-1.

Kim, WS., Rahman, M.M., Shimazaki K. (2008). Antibacterial activity and binding ability of bovine lactoferrin against Pseudomonas spp. J Food Saf, 28: 23-33, https://doi.org/10.1111/j.17454565.2007.00092.x.

Kim, WS., Ohashi, M., Shimazaki K. (2016). Inhibitory effects of synthetic peptides containing bovine lactoferrin C-lobe sequence on bacterial growth. Korean J Food Sci Anim Resour., 36(4): 452457, https://doi.org/10.5851/kosfa.2016.36. 4.452 .

Komine, K., Komine, Y., Kuroishi, T., Kobayashi, J., Obara, Y., Kumagai, K. (2005). Small molecule lactoferrin with an inflammatory effect but no apparent antibacterial activity in mastitic mammary gland secretion. J. Vet. Med. Sci., 67: 667-677, https://doi.org/10.1292/ jvms.67.667.

Kutila, T., Pyörälä, S., Saloniemi, H., Kaartinen, L. (2003). Antibacterial effect of bovine lactoferrin against udder pathogens. Acta Veterinaria Scandinavica, 44: 35-42, https://doi.org/10.1186/1751-0147-44-35.

Matijašic, BB., Oberckal, J., Lorbeg, PM., Paveljšek, D., Skale, N., Kolenc, B., Gruden, Š., Ulrih, NP., Kete M., Justin MZ. (2020). Characterisation of lactoferrin isolated from acid whey using pilot-scale monolithic ion-exchange chromatography. Processes, 8(7): 804 , https://doi.org/10.3390/pr8070804.

Meier, F., Lacroix, C., Meile, L., Jans, C. (2018). Enterococci and pseudomonads as quality indicators in industrial production and storage of mozzarella cheese from raw cow milk. Int Dairy J, 
82: 28-34, https://doi.org/10.1016/ j.idairyj.2018.02.010.

Melda, K. (2019). Süt ve süt ürünleri endüstrisinin sorunlar1 ve çözümlerinin analizi: Tekirdağ örneği. Namık Kemal Üniversitesi Sosyal Bilimler Enstitüsü İşletme Anabilim Dalı Yüksek Lisans Tezi, Tekirdağ, Türkiye, $33 \mathrm{~s}$.

Montiel, R., Martín-Cabrejas, I., Medina, M. (2016). Reuterin, lactoperoxidase, lactoferrin and high hydrostatic pressure on the inactivation of food-born pathogens in cooked ham. Innovative Food Sci Emerging Technol, 35: 111-118, https://doi.org/10.1016/j.ifset.2016.04.013.

Naidu, A.S. (2002). Activated lactoferrin - A new approach to meat safety. Food Technol, 56 (3): 4045.

Naidu, S.S., Svensson, U., Kishore, A.R., Naidu, A.S. (1993). Relationship between antibacterial activity and porin binding of lactoferrin in Escherichia coli and Salmonella typhimurium. Antimicrob. Agents Chemother, 37: 240-245, https://doi.org/10.1128/AAC.37.2.240.

O'Connell, A., Ruegg, P.L., Jordan, K., O’Brien, B., Gleeson, D. (2016). The effect of storage temperature and duration on the microbial quality of bulk tank milk. J. Dairy Sci., 99: 3367-3374, http://dx.doi.org/10.3168/jds.2015-10495.

Öztürk, Ü., Gürbüz, Ü., Çalım, H.D. (2006). Besinlerin muhafazasında bazı doğal antimikrobiyal sistemlerin rolü ve önemi. Türkiye 9. Gıda Kongresi; 24-26 May1s 2006, Bolu, Türkiye.

Padrão, C., Gonçalves, S., Silva J.P., Sencadas, V. Lanceros-Méndez, S., Pinheiro A.C., Vicente, A.A., Rodrigues, L.R., Dourado, F. (2016). Bacterial cellulose-lactoferrin as an antimicrobial edible packaging. Food Hydrocolloids. 58: 126-140, https://doi.org/10.1016/j.foodhyd.2016.02.019.

Papademas, P., Kamilari, E., Aspri, M., Anagnostopoulos, D.A., Mousikos, P., Kamilaris, A., Tsaltas, D. (2021). Investigation of donkey milk bacterial diversity by $16 \mathrm{~S}$ rDNA highthroughput sequencing on a cyprus donkey farm. Journal of Dairy Science, Vol.104, No.1, https://doi.org/10.3168/jds.2020-19242.
Payne, K.D., Oliver, S.P., Davidson, P.M. (1994) Comparison of EDTA and apo-lactoferrin with lysozyme on the growth of foodborne pathogenic and spoilage bacteria. J Food Prot, 57: 62-65, https://doi.org/10.4315/0362-028X-57.1.62.

Quigley, L., O'Sullivan, O., Stanton, C., Beresford, T.P., Ross, R.P., Fitzgerald, G.F., Cotter, P.D. (2013). The complex microbiota of raw milk. FEMS Microbiol. Rev., 37: 664-698, https://doi.org/10.1111/1574-6976.12030.

Quintieri, L., Caputo, L., Monaci, L., Deserio, Morea, M.,Baruzzi, F. (2012). Antimicrobial efficacy of pepsin-digested bovine lactoferrin on spoilage bacteria contaminating traditional Mozzarella cheese. Food Microbiol 31(1): 64-71, https://doi.org/10.1016/j.fm.2012.02.015.

Quinteri, L., Pistillo P.B., Caputo, L., Favia, P., Baruzzi, F. (2013). Bovine lactoferrin and lactoferricin on plasma-deposited coating against spoilage Pseudomonas spp. Innovative Food Sci \& Emer Technol, 20: 215-222, https://doi.org/10.1016/j.ifset.2013.04.013.

Quintieri, L., Zühlkeb, D.,Fanellia, F., Caputoa, L., Liuzzia, V.C., Logriecoa, A.F., Hirschfeldb, C., Becherb, D., Riedelb, K. (2019). Proteomic analysis of the food spoiler Pseudomonas fluorescens ITEM 17298 reveals the antibiofilm activity of the pepsin-digested bovine lactoferrin. Food Microbiol, 82: 177-193, https://doi.org/10.1016/ j.fm.2019.02.003.

Ruusunen, M., Salonen, M., Pulkkinen, H., Huuskonen, M., Hellström, S., Revez, J., Hanninen, ML., Fredriksson-Ahomaa, M., Lindström, M. (2013). Pathogenic bacteria in finnish bulk tank milk. Foodborne Pathogens and Disease, Vol.10, No.2, https://doi.org/10.1089/ fpd.2012.1284.

Robinson, R.K. (Ed.) (2005) Dairy microbiology bandbook: The microbiology of milk and milk products. Third Edition, John Wiley and Sons, Inc., Wiley Interscience Press, New York, USA, 737 p.

Sebastián-Nicolás, J.L., González-Olivares, L.G., Vázquez-Rodríguez, G.A., Lucho-Constatino, C.A., Castañeda-Ovando, A. (2020). Valorization of whey using a biorefinery. Biofuels, Bioprod. 
Bioref., 14: 1010-1027, https://doi.org/10.1002/ bbb. 2100 .

Steijns, J.M., van-Hooijdonk, A.C.M. (2000). Occurrence, structure, biochemical properties and technological characteristics of lactoferrin. British J Nutr, 84, Iss. S1: 11-17, https://doi.org/10.1017/S0007114500002191.

Tanaka, C., Yamada, K., Takeuchi, H., Inokuchi, Y., Kashiwagi, A., Toba, T. (2018). A lytic bacteriophage for controlling Pseudomonas lactis in raw cow's milk. Appl and Environ Microbiol, 84, Iss. 18: e00111-18, https://doi.org/10.1128/ AEM.00111-18.

Taylor, S., Brock, J., Kruger, C., Berner, T., Murphy, M. (2004). Safety determination for the use of bovine milk-derived lactoferrin as a component of an antimicrobial beef carcass spray. Regul Toxicol Pharmaco, 39: 12-24. https://doi.org/10.1016/j.yrtph.2003.10.001.

Temiz, H., Tarakçı, Z., Aylkut, U. (2008). Süt ve ürünlerinde mikroorganizmaları azaltmada alternatif yöntemler. Türkiye 10. Gida Kongresi; 21-23 Mayıs 2008, Erzurum, Türkiye.

Ternström, A., Lindberg, A.M., Molin, G. (1993). Classification of the spoilage flora of raw and pasteurized bovine milk, with special reference to Pseudomonas and Bacillus. J. Appl. Bacteriol., 75: 25-
34.

https:// doi.org/10.1111/j.13652672.1993.tb03403.x.

Tonguc-Altin, K., Sandall, A., Duman, G., Selvi Kuvvetli, S., Topçuoğlu, N., Külekçi, G. (2015). Development of novel formulations containing lysozyme and lactoferrin and evaluation of antibacterial effects on Mutans Streptococci and Lactobacilli. Archives of Oral Biology, 60(5): 706-714, https://doi.org/10.1016/ j.archoralbio.2015.02.004.

Ünal, G., Akalın, S.A. (2008). Süt proteini kaynaklı peptidlerin antibakteriyel aktivitesi. Türkiye 10. Gida Kongresi; 21-23 Mayıs 2008, Erzurum, Türkiye.

Wakabayashi, H., Yamauchi, K., Takase, M. (2006). Lactoferrin research, technology and applications. Int Dairy J, 16: 1241-1251, https://doi.org/10.1016/j.idairyj.2006.06.013.

Walstra, P., Wouters, J.T.M., Geurts, T.J. (2006). Dairy science and technology, Second Edition, Taylor \& Francis Group, CRC Press, Boca Raton FL, USA, $763 \mathrm{p}$.

Yilmaz, B., Tosun, H. (2012). Sütte bulunan doğal antimikrobiyal sistemler ve bunların gida sanayinde kullanımı. Celal Bayar Üniversitesi Fen Bilimleri Dergisi, 9 (1): 11-20. 